親潮及び親潮潛流に就て

$$
\text { 中央氣哀台福岡二即 }
$$

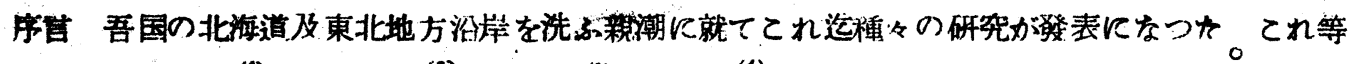

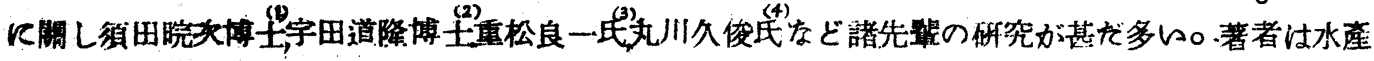

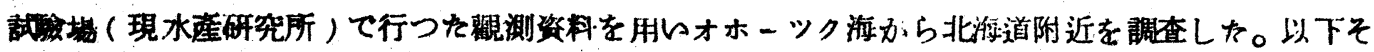
の結果てある。

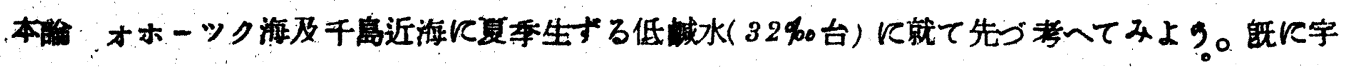
田博士に依り冬才ホーツク海ては水案 $100 \mathrm{~m}$ 附近迄對流が盛んててれが复季生成される中冷看水

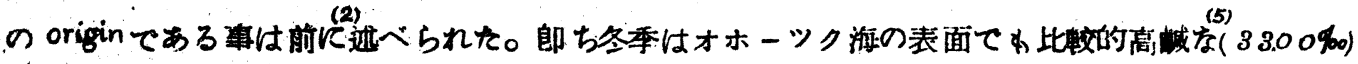

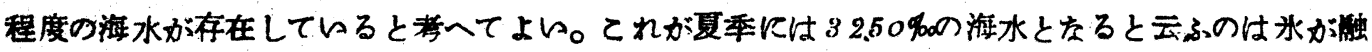
けるのが取大の原因てある事には疑らの余地がない。

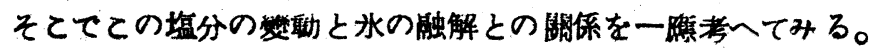

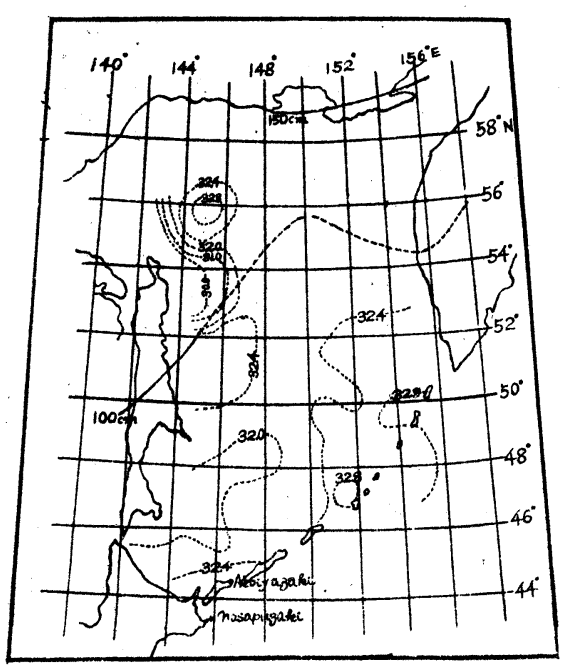

Fig. 1. Showing salinity and thickness of ice in Othotsk-Sea. (-.- Salinity of surface, - - - thickness of ice) [The distribution of salinity on surface from the paper made]
オホーツク海の全面䅡は約 $151 \times 10^{4} \mathrm{Km}^{2 *}$

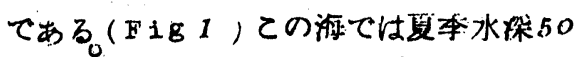

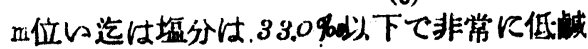
な水が存在してるる事は種くの)糧測から判 つている。ての値として大体 $32.6 \% 00$ 値を とつた。（N181参照）冬季怙觀湘値がな らので確かな料は云へないが字壮博士の論 文からわ33.04程度でる其加判る。

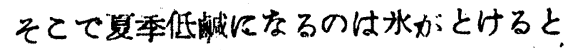
して陸水雨水蒸矮等怙考へ才゙に計算してみ

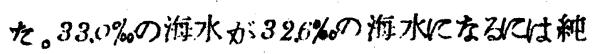

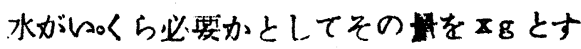
उと $\quad \frac{33.0}{1000+x}=\frac{32.6}{1000} \quad \mathrm{x}=12.2 \mathrm{~g}$

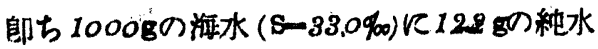
が必要でる。

※ 理科年表より 
今海水 $1000 \mathrm{~g}=1025 \mathrm{cC}$ と考へると

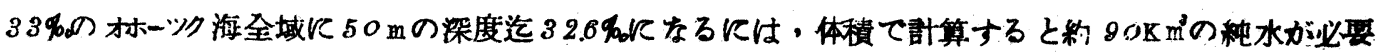
と云ふ事にをる。一方氷の量の実測値をみよう。

水路誌等には千島列島模太カムザカ牛島等の港の結氷狀態部分的に述べてあるがオホーツク海全

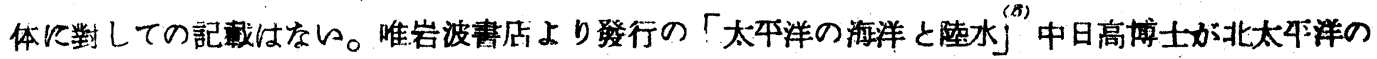

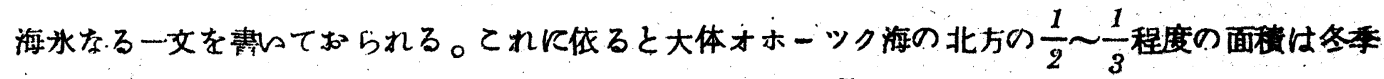
結水し交通が杜絕するとの事である。氷の厚さは大体 $1^{\mathrm{m}} \sim 2$ 程度であるらしい。

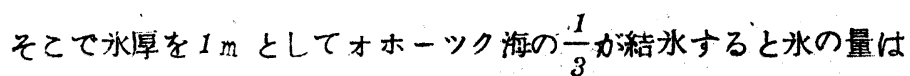

䄪 $50 \mathrm{Km}^{3}$ 水涅を $2 \mathrm{~m}$ とすれは士 約 $100 \mathrm{Km}$

面積の $\frac{1}{2}$ 結水すると水焻 $1 \mathrm{~m} \theta$ 垗合

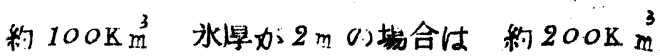

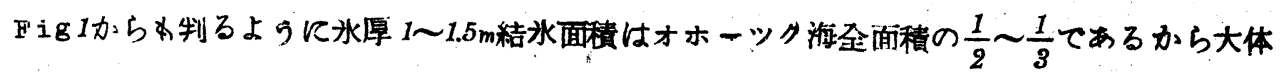
orderはー致する。

ては水のとける程度と海水の塭分の低くなる度合とが大体一致する゙のとすると海洋粯測の結果

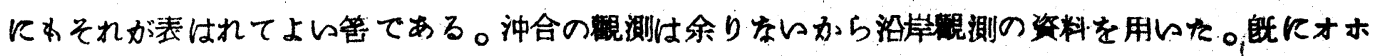
一ック海の表面の流れは丸川久俊氏重松良一氏等によりあないられている。てれらの結果から千岛

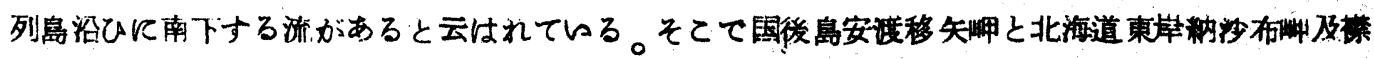

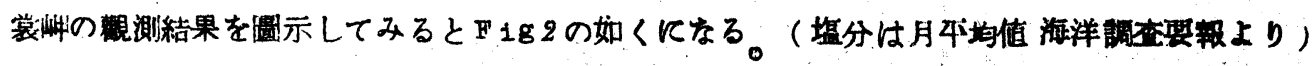

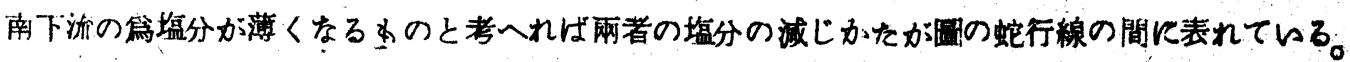

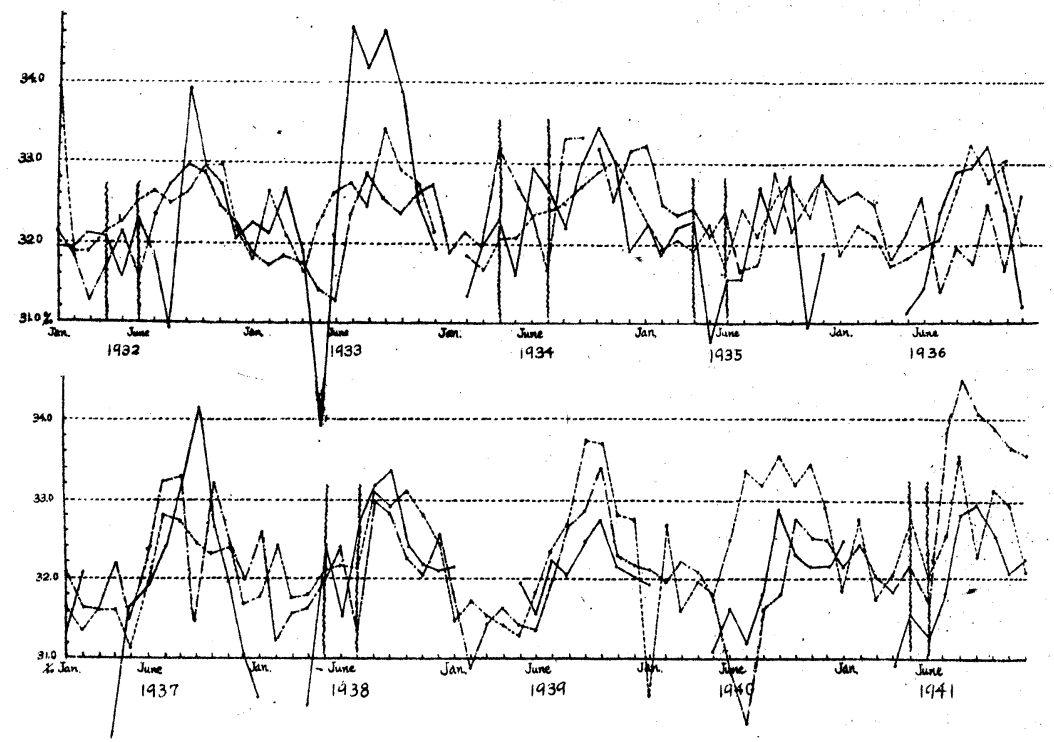

Fig. 2. Showing Salinity at Atoiyazaki, Nosappuzaki and Erimomisaki.
この逛れの期間 と两者の距㒕加ら 表面流か知定され ると教た。 そ の結果はb10Iの 通りてある。 てれらの值を福 ろ為には次の槏に 考人た裂で b。 安教移矢神之納沙

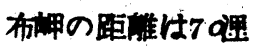

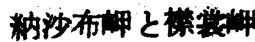




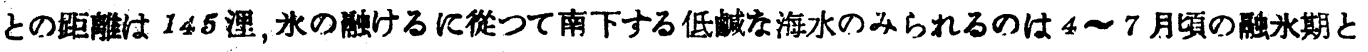

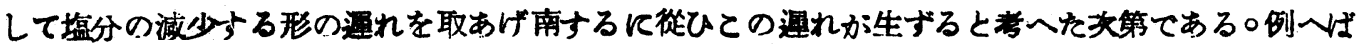

\section{Iable I}

\begin{tabular}{|c|c|c|}
\hline year & The velocity of Current (Oyashio) & \\
\hline 1932 & $0.2^{\text {(knot) (Atoiya - Erimo) }}$ & 0 \\
\hline 33 & - & 0 \\
\hline 34 & $0.1 \quad$ (Atoiya-Erimo) & $\times$ \\
\hline 35 & $0.1-0.2 \quad$ (Atoiya -Nosappu-Erimo) & \\
\hline 36 & - & 0 \\
\hline 37 & - & 0 \\
\hline 38 & $0.1-0.2$ (Atoiya -Nosappu-Erimo) & \\
\hline 39 & - & 0 \\
\hline 40 & - & 0 \\
\hline 41 & Strong (Atoiya- Nasappu) & $\times$ \\
\hline
\end{tabular}

- showing that the Kuroshio (warm-current) is strong.

$x$ showing that the Oyashio (cold-current) is very strong.

(- showing that the velocity of Oyashio cannot be gotten.

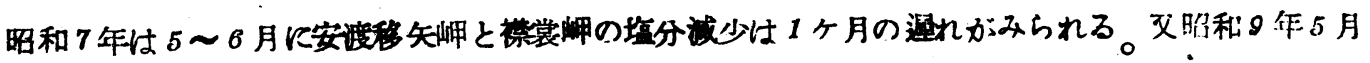

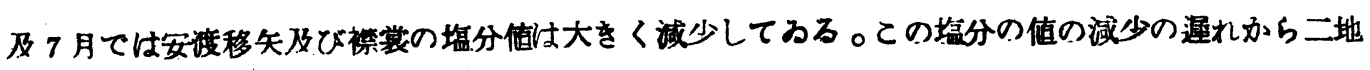

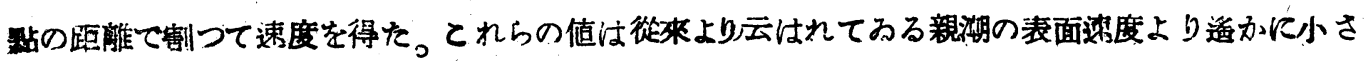

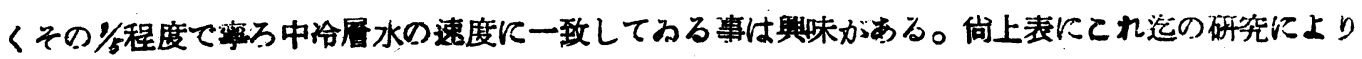

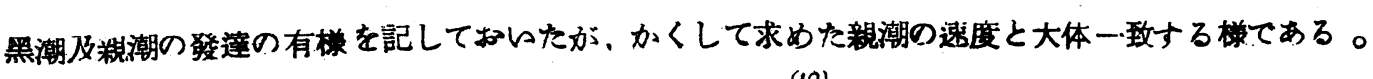
かくの如く海流の速度を決定するととはの.I.R.Dea00nか溉に大西洋て酸素最の枢大值とその間 の距離とから中屏水の速度を求かたのと軌を一にしてるて別に目新しい事てはない。舞近北海道大

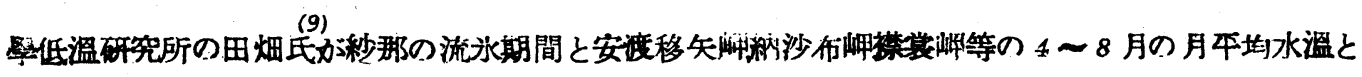

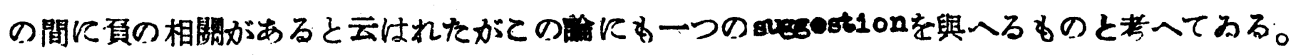

以上表面流に就て考察したが次に中㡟水に就て述べよす。

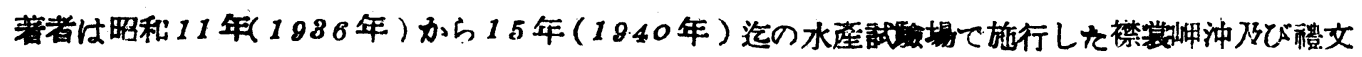

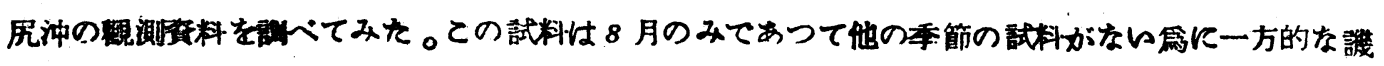
りを免れないがてれは怒して戴く事にする。（F18 3）

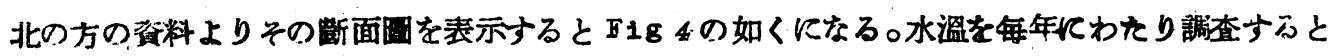




\section{Fig. 3. Oceanographical Station from 1936 to/940}

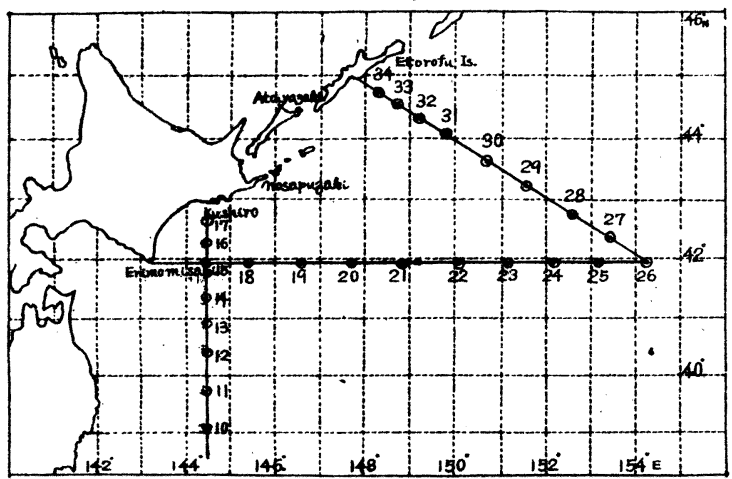

几高溫部と高水とはよく一致する。
夷の棁なととが云いる。

1. St. 2 26 附近て恃常に 300 ー500mの部迄高温 ( $5^{\circ} \mathrm{C}$ 以上) ある。

2. 年化より St.1 2 20 时近て 200 400mの酸 $5^{\circ} \mathrm{C}$ 以上の水 溫が楒められる。

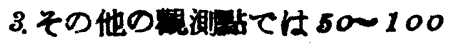
mの所に非常索低温部が存在して 万る。 $\left(1 \sim 20^{\circ}\right.$ 内外 )

\section{㙁分について輸べる}

2.低溫部ては $33.00 \%$ \% $33.70 \% 0$ 程度てあ⿸厂万力口

3.500れ位の部ては大体 34 多以上となり深度を增すとつれて塩分が坦して行く事が制る。 現場媱度に就て

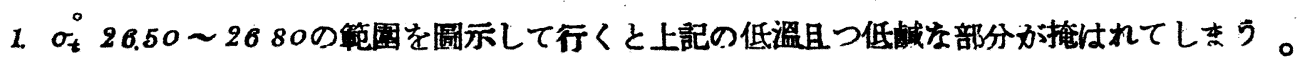
(Fig 4 盟)

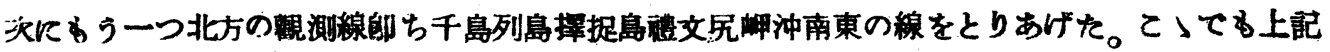

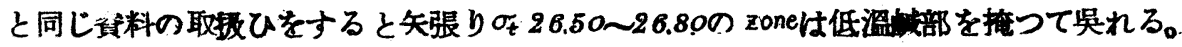

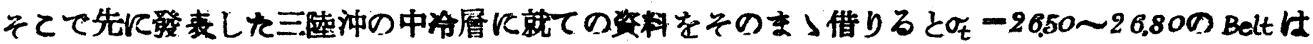
金華山沖の不連程屠によく一致してるる。

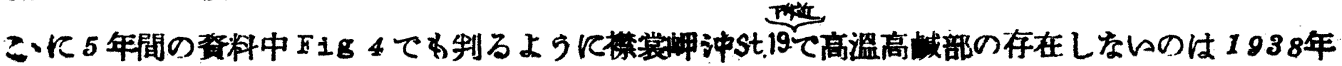
丈でる。

5 年間の会料を整理して费くと

Fig.4. Section for Density in situ in Aug. 1937.

Fig. 5. Section for Density in situ in Aug. 1936.
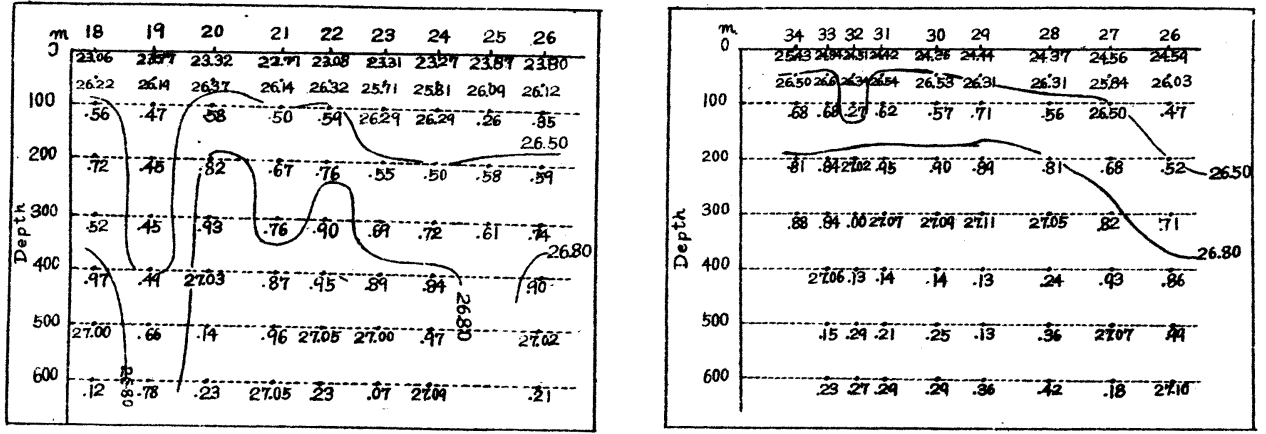


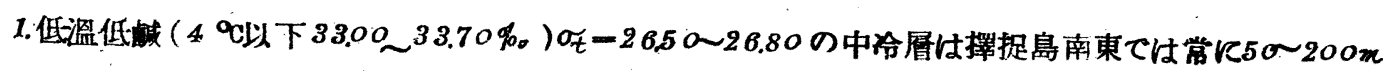
梁さに拱がりSt26 附近で始めて 200 以 以梁に潛つてふる。

2.襟裳岬東では年により轵なる。

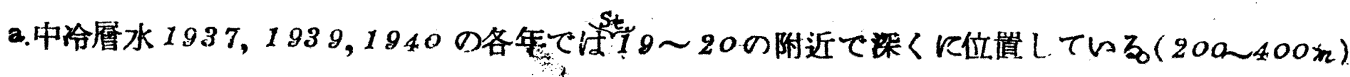

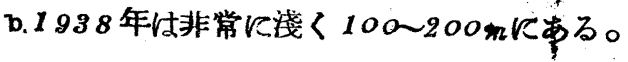

Fig. 6. Section for Water-temperature and Salinity
(a) Feb. 1937
(b) Feb. 1938

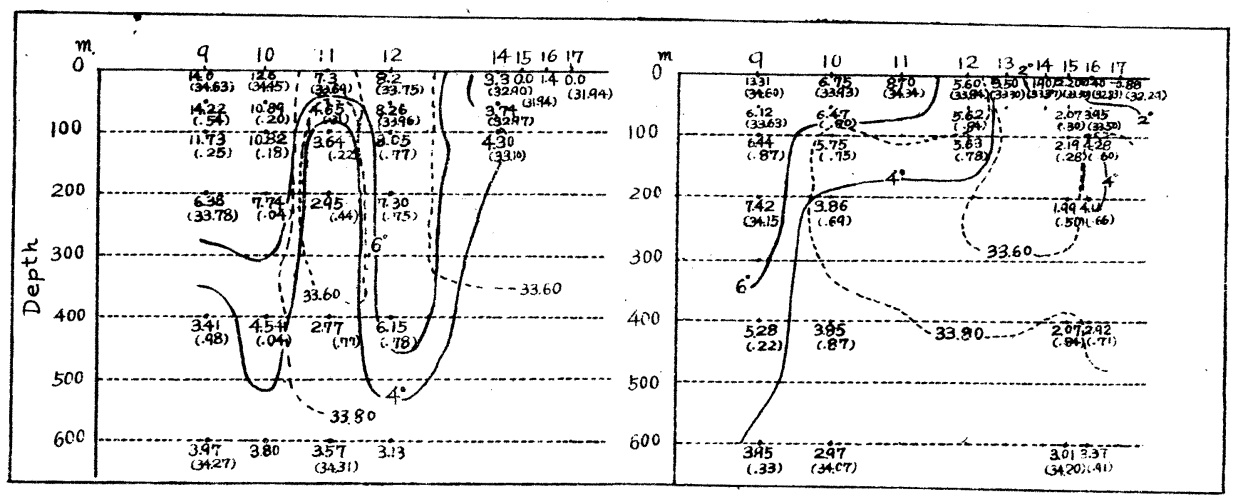

ての中命層の深く乃至淺く岁差は何んであるか、釗路沖の 8 月の觀測を調べると染くなる場合

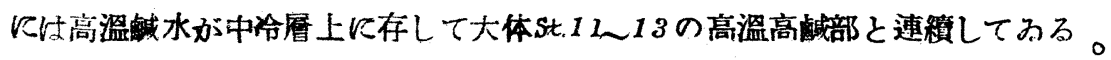

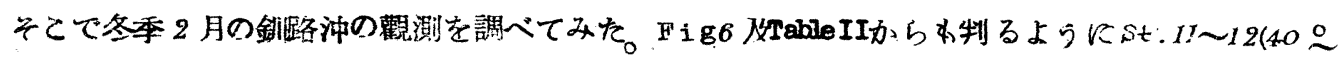
$39^{\circ}$ ) 附近に特に舌狀に高溫高堿の水が認められる場合と連樍的に變化してかる場合とがあか。 Table II の中曾線で图んでる場合が高溫高晟部を示してわるのであるが、現象丈で說明すると斯

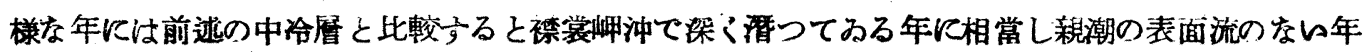
にる一致する。

結語 親潮に關し表面流及び潛流(中泠層)に就ててれ迄現象的に述べたに過な゙ない。

しかしての現象より親潮及潛流が軌を一にして勢力学增大し又冬季より暖流が强い場合には親潮

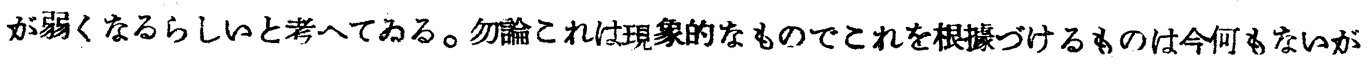
今後ての方向を進めたいと考へてみるから諸先脾の御比正希望して止まない。

(1950年 3 月)

参考文都

(1)須田 晥认 日本近海表面水㵊の異狀分布に就て 產業氣象調查報告 第 4 卷 昭和 9 年

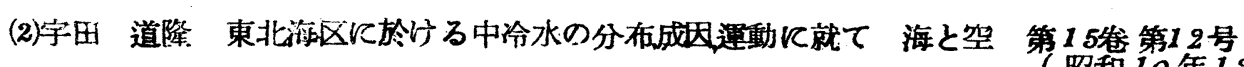


Table II

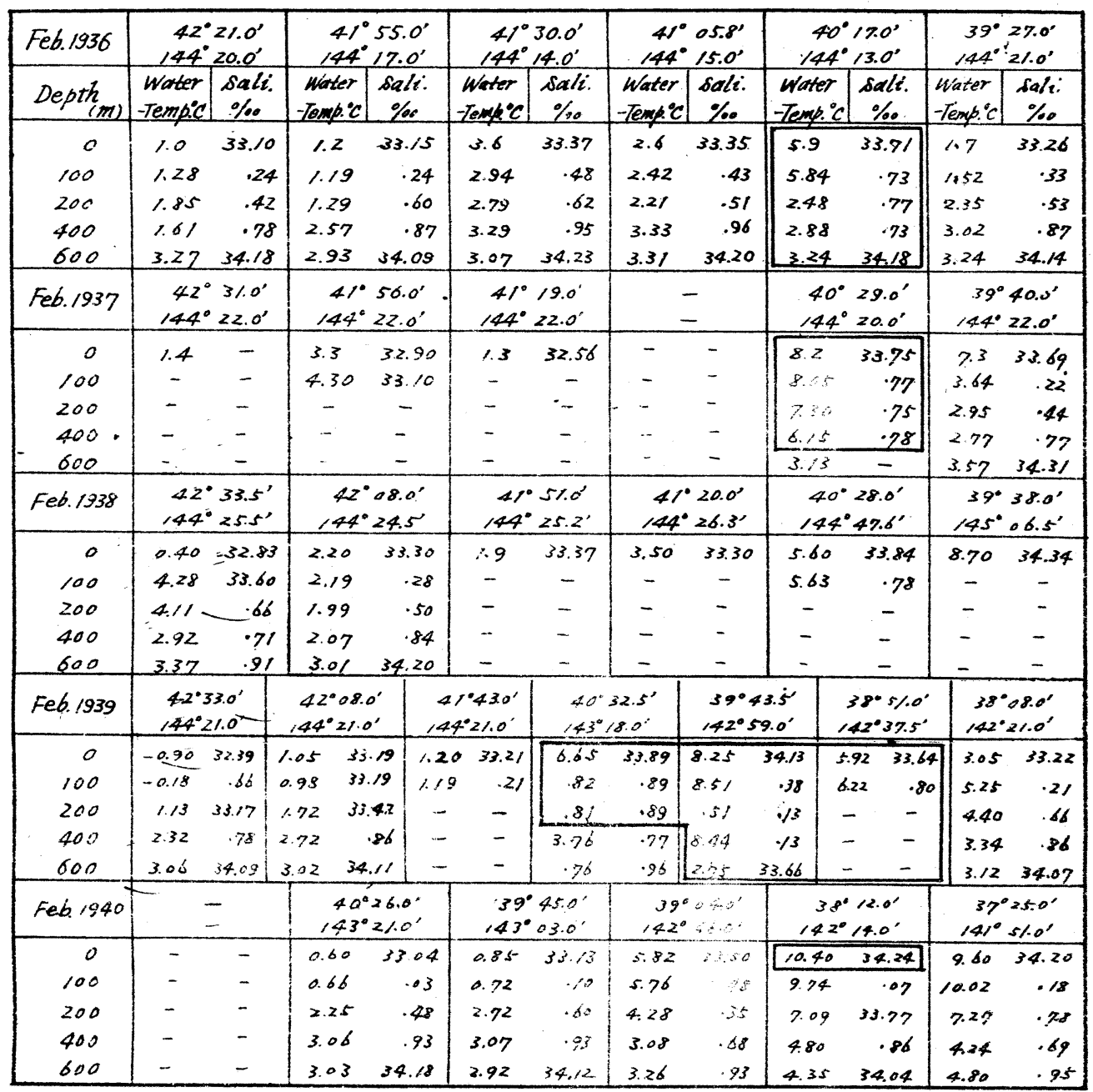

(Datas from Oceanographicai Report, The Imberial Fisheries Exporimental Station)

(3)重松 良一 才小ーツ以海の海流及親潮の起源等に就? 水路琵辩、第 8 号第 12 年昭和 8 年

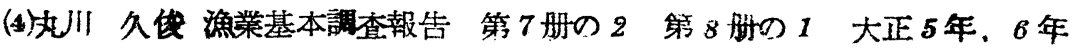

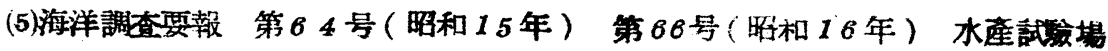

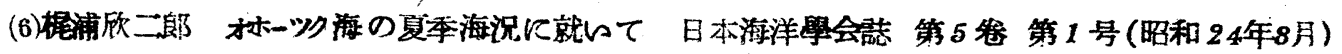

(7)水 路 誌 オホーツク海及び千島

(8)日高 拳次 太平洋の海水に就て「太平洋の海洋と陸水」

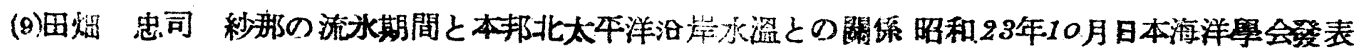

(10)G. E. R. Deacan: Mature Aug. 15, 1931, London. 


\section{The ojashio and the ojashio Creeping Current.}

\section{By J1ro Fukuoka.}

The sea-water of low salinity (about 32.6\%) is in existence near okhotuak Sea from surface to $50 \mathrm{~m}$ depth in sumer.

It 18 sald that the sea-water is relation with the 1co-melting volume. So from the difference of salinity value of summer and winter, the outhor studied the relation of the 1ce-melting volume and the degree of decrease of salinity. From this conclueion, studing the salinity-yalue in Ato1yazak1, Nosappusekt, and Erimo-misak1, In 1ce-melting season the degree of deccease of salinity appears late in south-Station.

Owing to late, the velopity of the cold-current is decided(Table I). Iext, 3tuding the oceanographical observation of the south-east regioneff Kunashiri I.,the east region off Erimo-misaki, and the south region off Kushiro from 1936 to 1940, the distribution of the dichotherm layer is decided. So from this researoh, it seems that the velosity of the cold ourrent has relations with the distribution of the cold current. 